\title{
PENINGKATAN HASIL BELAJAR DENGAN METODE BERMAIN PERAN PADA MATA PELAJARAN BAHASA INGGRIS DI KELAS IV MI THORIQOTUL FALAH TALANGKEMBAR TAHUN PELAJARAN 2017/2018
}

\author{
Akhmad Aji Pradana, email: ajipradana@stitmatuban.ac.id \\ Annisa Ulfa'atin Sholihah
}

\begin{abstract}
English is an international language that is important to learn because English can be used to communicate with any nation. Along with the above, learning English needs to be introduced to students as early as possible. The limited allocation of time in learning English has an impact on the lack of level of student understanding and enthusiasm of students in English subjects, so that the achievement of learning outcomes is also far from the minimum standards of completeness set by the institution. This study aims to increase the level of activity and enthusiasm of students in learning English, improve student learning outcomes in English subjects. This research method uses classroom action research (Action Classroom Research) with a learning approach using a cycle and described using descriptive analysis methods. Qualitatively, namely by observing to obtain student attitudes data during the process of teaching and learning activities (KBM) and teachers in applying methods in learning. While quantitative is to process data in the form of numbers from formative test results in each cycle. Descriptive analysis is intended to explain the recapitulation of qualitative data obtained during KBM. The research subjects were class IV MI Thoriqotul Falah Talangkembar District Montong Tuban Regency, with the number of students 19 children consisting of 10 female students and 9 male students with heterogeneous student abilities. From the results of this study it can be concluded that, the use of role playing methods has an effect on improving student learning outcomes. Recapitulation of the acquisition of the class average of 67.5 at the pre cycle stage, 75.68 in the first cycle, and 77.37 in the second cycle. The number of students completing learning increases each cycle, initially 9 students at the pre-cycle stage, 12 students in the first cycle, and 17 students in the second cycle. Classical completeness also reached the target height of $89.50 \%$ at the end of the second cycle, from $43.36 \%$ at the beginning of the cycle and $75.68 \%$ at the cycle I stage.
\end{abstract}

Keywords : learning outcomes, role-playing method, english lesson in MI 


\section{Pendahuluan}

Di era globalisasi seperti sekarang ini, perkembangan pesat terjadi di segala bidang, termasuk bidang teknologi dan informasi yang menjadi pemicu dimulainya era revolusi industri 4.0. Bersamaan dengan itu, untuk menghadapi tantangan tersebut sudah seharusnya kita juga meningkatkan kemampuan individu. Salah satu kemampuan dasar yang paling penting untuk ditingkatkan adalah kemampuan berbahasa asing karena kemampuan tersebut diperlukan untuk komunikasi antar negara dan pertukaran informasi untuk menunjang perkembangandi berbagai bidang.

Bahasa Inggris merupakan bahasa internasional dan paling banyak digunakan di berbagai belahan dunia. Dengan demikian bahasa Inggris menjadi penting untuk dipelajari karena bahasa Inggris bisa digunakan untuk berkomunikasi dengan bangsa manapun. Seiring dengan adanya hal diatas, maka pembelajaran bahasa Inggris perlu dikenalkan kepada anak didik sedini mungkin. Dalam pendidikan yang telah dilaksanakan, bahasa Inggris telah diajarkan kepada anak didik sejak di bangku sekolah dasar. Pembelajaran bahasa Inggris di tingkat dasar merupakan pembelajaran awal bagi anak didik untuk mengenal pelajaran Bahasa Inggris. ${ }^{1}$

Ruang lingkup pembelajaran Bahasa Inggris di SD/MI mencakup kemampuan berkomunikasi lisan secara terbatas dalam konteks sekolah, yang meliputi aspek-aspek sebagai berikut, yakni: (1) mendengarkan (listening); (2) berbicara (speaking); (3) membaca (reading); dan (4) menulis (writing). Keempat keterampilan tersebut harus terpenuhi dalam setiap pembelajarannya, sehingga setelah adanya pembelajaran siswa akan selalu memiliki keterampilan yang dirumuskan dalam tujuan pembelajaran.

Akan tetapi, fakta di lapangan menunjukkan bahwa kebijakan kurikulum tentang alokasi waktu padapembelajaran Bahasa Inggris dirasa kurang bagi guru untuk melaksanakan pembelajaran secara menyeluruh sesuai dengan tuntutan tujuan pembelajaran yang telah dirumuskan. Keterbatasan alokasi waktupada pembelajaran bahasa inggris berdampak pada kurangnya tingkat pemahaman siswa dan antusiasme siswa pada mata pelajaran Bahasa Inggris, sehingga pencapaian hasil belajar juga jauh dari standar ketuntasan minimal yang di tentukan lembaga.

Berdasarkan uraian permasalahan diatas, maka diperlukan metode pembelajaran yang sesuai untuk meningkatkan keaktifan dan antusiasme serta hasil belajar siswa. Model

\footnotetext{
${ }^{1}$ Mukarto dkk, Grow With English, Jakarta: Erlangga,2007
} 
pembelajaran Bermain Peran (Role Playing) merupakan sebuah model pembelajaran yang diarahkan pada pemecahan masalah-masalah yang menyangkut hubungan antarmanusia, terutama kehidupan peserta didik. Model pembelajaran ini juga melatih anak didik untuk menjunjung tinggi nilai-nilai demokratis.

Dalam metode pembelajaran jenis ini siswa akan mempraktikkan materi pembelajaran dengan berperan sesuai tema yang ditentukan dan berkaitan dengan materi yang dipelajari. Dengan adanya praktik secara langsung, siswa akan mudah memahami penggunaan ungkapanungkapan serta pola kalimat dalam Bahasa Inggris dan mudah mengingatnya. Dengan pemahaman dan daya ingat yang tinggi, maka hasil belajar siswa diharapkan juga akan mengalami peningkatan sesuai kriteria ketuntasan minimal sesuai dengan tujuan yang ditetapkan.

Kegiatan belajar mengajar dengan menerapkan metode belajar dengan bermain peran dipandang sebagai pengalaman belajar yang mengarahkan siswa kepada prestasi siswa yang tinggi. Lingkungan belajar dengan pengalaman langsung akan sangat potensial untuk dapat membimbing siswa dalam pengembangannya. Namun demikian, dalam situasi pembelajaran bentuk apapun, pengembangan kemampuan siswa tidak akan berkembang apabila guru kurang menguasai dalam mengelola kelas. Dalam pelaksanaan kegiatan belajar mengajar guru harus menjadi mediator dan fasilitator yang baik sehingga proses pembelajaran yang sudah dirancang akan terlaksana dengan baik.

Berdasarkan uraian permasalahan di atas, penelitian ini bertujuan untuk meningkatkan tingkat keaktifan dan antusiasme peserta didik dalam pembelajaran Bahasa Inggris serta meningkatkan hasil belajar siswa dalam mata pelajaran Bahasa Inggris.Selanjutnya, beberapa manfaat yang dapat diajukan dalam penelitian ini adalah; menambah pengetahuan tentang pemanfaatan model belajar bermain peran (Role Playing) sebagai metode pembelajaran di kelas, menambah motivasi guru untuk menerapkan berbagai strategi, model, dan metode pembelajaran yang lebih bervariasi sehingga mata pelajaran yang disampaikan lebih menarik perhatian siswa, mengatasi problema pembelajaran yang selama ini banyak dikeluhkan terutama berkaitan dengan pembelajaran Bahasa Inggris.

\section{Kajian Teori}

Guru kreatif senantiasa mencari pendekatan-pendekatan baru dalam memecahkan masalah, tidak terpaku pada cara tertentu yang monoton, melainkan memilih variasi lain yang tepat. 
Bermain peran merupakan salah satu alternatif yang dapat digunakan secara efektif dalam pembelajaran. Melalui bermain peran, para peserta didik mencoba mengeksplorasi hubungan antarmanusia dengan cara memperagakannya dan mendiskusikannya sehingga secara bersamasama para peserta didik dapat mengeksplorasi perasaan, sikap, nilai, dan berbagai strategi pemecahan masalah. ${ }^{2}$

Role playing (bermain peran) merupakan sebuah model pengajaran yang berasal dari dimensi pendidikan individu maupun sosial. Model ini membantu masing-masing siswa untuk menemukan makna pribadi dalam dunia sosial mereka dan membantu memecahkan dilema pribadi dengan bantuan kelompok. Dalam dimensi sosial, model ini memudahkan individu untuk bekerja sama dalam menganalisis kondisi sosial, khususnya kemanusiaan. Model ini juga menyokong beberapa cara dalam proses pengembangan sikap sopan dan demokratis dalam menghadapi masalah. Esensi role playing adalah keterlibatan partisipan dan peneliti dalam situasi permasalahan dan adanya keinginan untuk memunculkan resolusi damai serta memahami apa yang dihasilkan dari keterlibatan langsung ini.Sintak dalam role playing dibagi menjadi beberapa tahap adalah sebagai berikut:1). Pemanasan Suasana Kelompok; 2) Seleksi Partisipan; 3) Pengaturan Setting; 4) Persiapan Pemilihan Siswa sebagai Pengamat; 5)Pemeranan; 6) Diskusi dan Evaluasi; 7) Pemeranan Kembali; 9) Sharing dan Generalisasi Pengalaman. ${ }^{3}$

Setiap hal pasti memiliki kelebihan dan kekurangan. Begitu pula dengan metode ini. Beberapa kelebihan metode bermain diantaranya adalah: 1)Siswa melatih dirinya untuk melatih, memahami, dan mengingat isi bahan yang akan didramakan; 2)Mempertajam daya ingatan siswa; 3)Siswa akan terlatih untuk berinisiatif dan berkreatif; 4)Memaksimalkan bakat seni siswa; 5)Menumbuhkan sikap kerjasama dan tanggung jawab dengan sesamanya; 6)Melatih bahasa lisan siswa.

Sedangkan untuk kekurangan metode bermain peran adalah: 1)Banyak memakan waktu; 2)Memerlukan tempat yang cukup luas; 3)Mengganggu kondusifitas kelas lain; 4)Hambatan berupa kurangnya rasa percaya diri pada siswa; 5)Apabila pelaksanaan dramatisasi gagal, maka

${ }^{2}$ Mulyasa,Manajemen Pendidikan Karakter, Cet IV, Jakarta: PT. Bumi Aksara, 2014, hal : 179 ${ }^{3}$ Miftahul Huda, Model-model Pengajaran dan Pembelajaran: Isu-isu Metodis dan Paradigmatis, Cet III, Yogyakarta: Pustaka Pelajar, 2013, hal :115 - 117 
guru tidak dapat mengambil sesuatu kesimpulan apapun yang berarti pula tujuan pengajaran tidak dapat tercapai. ${ }^{4}$

\section{Metode}

Penelitian ini merupakan penelitian tindakan kelas (PTK) dengan pendekatan kualitatif dan analisis deskriptif. Penelitian ini bertujuan untuk meningkatkan keaktifan dan antusiasme peserta didik dalam pembelajaran Bahasa Inggris serta meningkatkan hasil belajar siswa dalam mata pelajaran Bahasa Inggris.

Tahapan dalam siklus PTK terdiri atas perencanaan, tindakan, observasi, dan refleksi. Selanjutnya desain Penelitian Tindakan Kelas dalam penelitian ini dirancang untuk dapat menyelesaikan satu pokok bahasan yang akan dilaksanakan secara berkelanjutan dengan menggunakan dua siklus.Guru dan peneliti terlibat langsung sejak dari rencana, pelaksanaan, observasi sampai pada refleksi. Siswa dan guru aktif di dalam KBM. Peneliti/observer bertugas mengamati guru maupun siswa di dalam KBM. Data dari guru berkenaan dengan tindakantindakan yang diberikan sedangkan data dari siswa berkenaan dengan pendapat serta perubahan sikap yang terjadi karena tindakan tersebut.

Subjek dalam penelitian ini adalah kelas IV MI Thoriqotul Falah di Dusun Daringan Desa Talangkembar Kecamatan Montong Kabupaten Tuban, dengan jumlah siswa 19 anak, yang terdiri dari 10 siswa perempuan dan 9 siswa laki-laki. Keadaan kelas bersifat heterogen serta kemampuan siswa dalam kondisi rata-rata.

Instrumen yang digunakan dalam penelitian ini adalah instrumen tes dan nontes. Instrumen tes berupa soal tes formatif, sedangkan instrumen nontes berupa lembar observasi,lembar penilaian unjuk kerja, serta angket respon siswa.

Untuk mengukur keberhasilan dari pembelajaran ini, dapat dilihat dari 2 (dua) indikator, yakni indikator kualitatif dan indikator kuantitatif. Indikator kualitatif dapat dinyatakan berhasil apabila perilaku peserta didik mengarah kepada hal-hal berikut: (1) lebih antusias dan termotivasi dalam belajar, (2) bersikap santun dan tertib dalam mengikuti pembelajaran, dan (3)

\footnotetext{
${ }^{4}$ Rizky,Kelebihan dan Kelemahan Metode Bermain Peran atau Sosiodrama, (Online), http://pedulidenganmenulis.blogspot.co.id/2013/02/kelebihan-dan-kelemahan-metodebermain.html, 2013, (diakses tanggal 30 Maret 2018).
} 
siswa aktif dalam proses pembelajaran. Sedangkan untuk indikator kuantitatif dapat dilihat dari nilai yang mencapai ketuntasan belajar. Terdapat dua kategori ketuntasan belajar, yaitu secara individu dan klasikal.Ketuntasan individual dapat tercapai apabila nilai siswa dapat memenuhi KKM sebesar $\geq 70$. Sedangkan ketuntasan klasikal dapat dikatakan tercapai apabila di kelas tersebut terdapat $85 \%$ yang telah memenuhi KKM.Data yang diperoleh pada penelitian ini berupa data kualitatif dan data kuantitatif yang selanjutnya akan dianalisis menggunakan analisis deskriptif.

\section{Hasil dan Pembahasan}

Data hasil penelitian tindakan kelas ini diperoleh dari penilaian yang dilakukan selama proses pembelajaran Bahasa Inggris materiSpelling dan Imperative Sentencesdi kelas IV MI Thoriqotul Falah,yang berlangsung melalui 2 siklus pembelajaran dengan alokasi waktu $4 \mathrm{x}$ pertemuan $2 \times 35$ menit/ pertemuan.

Tahap pra penelitian dilakukan dengan mengadakan observasi awal terlebih dahulu. Dimana dalam tahap observasi tersebut guru mengajar dengan metode seperti biasanya. Hasil penelitian yang disajikan dan dibahas meliputi hasil observasi selama Kegiatan Belajar Mengajar (KBM) berlangsung, hasil angket siswa yang di isi pada setiap akhir siklus dan hasil ulangan sebelum dan setiap akhir-akhir siklus. Hal ini digunakan sebagai tolak ukur untuk melihat hasil perkembangan pencapaian setiap pembelajarannya. Sebelum siklus I dilakukan, peneliti mengadakan refleksi awal dengan maksud untuk mengetahui kemampuan siswa sebelum dilaksanakan tindakan kelas. Nilai rata-rata kelas 67,5 Hal inilah yang mendorong peneliti untuk melakukan penelitian tindakan kelas dengan menggunakan metode bermain peran, dengan tujuan anak dapat mencapai keempat aspek keterampilan berbahasa dalam pelajaran Bahasa Inggris.

Pelaksanaan kegiatan belajar mengajar untuk siklus I dilaksanakan pada tangal 24 Januari dan 31 Januari 2018 di kelas IV MI Thoriqotul Falah Talangkembar Kecamatan Montong Kabupaten Tuban. Jumlah siswa 19 anak. Dalam hal ini peneliti bertindak sebagai mitra guru/observer. Peneliti bertugas mencatat setiap hal yang terjadi selama proses pembelajaran berlangsung, hal dicatat meliputi tindakan-tindakan guru serta sikap/perilaku siswa 
selama diberi tindakan dan menilai siswa selama proses pemeranan dalam lembar penilaian unjuk kerja.Rekapitulisasi data hasil tes pada siklus 1 disajikan dalam Tabel 4.1.

Tabel 4.1 Hasil Evaluasi Pembelajaran Siswa Siklus 1

\begin{tabular}{|c|l|c|c|}
\hline \multirow{2}{*}{ No } & \multirow{2}{*}{ Hasil Evaluasi Pembelajaran Siswa Siklus 1 } & \multicolumn{2}{|c|}{ Hasil } \\
\cline { 3 - 4 } & & 12 & 63,15 \\
\hline $\mathbf{1}$ & Jumlah siswa yang tuntas belajar & 7 & 36,85 \\
\hline $\mathbf{2}$ & Jumlah siswa yang tidak tuntas belajar & \multicolumn{2}{|c|}{$\mathbf{7 5 , 6 8}$} \\
\hline Rata-rata kelas (Mean) & \multicolumn{2}{|c|}{$\mathbf{6 3 , 5 \%}$} \\
\hline Ketuntasan klasikal & \multicolumn{2}{|c|}{} \\
\hline
\end{tabular}

Bedasarkan Tabel 4.1 dapat diketahui bahwa setelah kelas diberi tindakan, hasil belajar siswa mengalami peningkatan. Rata-rata kelas yang semula hanya 67,5 menjadi 75,68. Jumlah siswa tuntas meningkat dari 9 anak ke 12 anak. Nilai tengah yang semula 60 menjadi 80, modus dalam siklus I ini adalah 100. Persentase ketuntasan belajar secara klasikal meningkat dari 47,36\% menjadi 63,15\%. Akan tetapi pencapaian ketuntatasan klasikal ini belum sesuai dengan ketuntasan yang dikehendaki $(\leq 85 \%)$.

Selaian melakukan tes evaluasi, peneliti melakukan pengamatan yang difokuskan pada kegiatan guru dalam memberi tindakan serta pengamatan tentang sikap siswa saat pembelajaran berlangsung dengan tindakan kelas yakni metode bermain peran (role playing). Hasil pengamatan sikap siswa pada pembelajaran di siklus I dapat disajikan dalam Tabel 4.2.

$\mathrm{Tab}$

\begin{tabular}{|c|l|c|c|c|c|}
\hline \multirow{2}{*}{ No. } & \multicolumn{2}{|c|}{ Uraian } & \multicolumn{4}{c|}{ Jumlah } \\
\cline { 3 - 6 } & & Ya & $\%$ & Tidak & $\%$ \\
\hline 1. & Semangat siswa dalam belajar & 12 & 63,15 & 7 & 36,85 \\
\hline $\mathbf{2 .}$ & Antusiasme siswa dalam belajar & 7 & 36,85 & 12 & 63,15 \\
\hline 3. & Keaktifan dan respon siswa dalam belajar & 10 & 52,63 & 9 & 47,37 \\
\hline 4. & Kekritisan siswa dalam belajar & 5 & 26,31 & 14 & 73,69 \\
\hline $\mathbf{5 .}$ & Disiplin siswa dalam mengikuti pelajaran & 10 & 52,63 & 9 & 47,37 \\
\hline
\end{tabular}

el

Has il Pen ga mat an Akt 


\section{ifitas Sikap Siswa Pada Siklus 1}

Berdasarkan Tabel 4.2 dapat diketahui bahwarespon sikap siswa terhadap penerapan model pembelajaran bermain peran masih sangat rendah. Hal tersebut ditunjukkan dengan rendahnya tingkat kekritisan siswa dalam belajar,karena siswa belum memahami betul tentang apa yang dimaksudkan dalam metode bermain peran. Akan tetapi dalam pertemuan kedua mereka sedikit lebih aktif serta dapat menanggapi tentang apa yang diberikan oleh guru kepada mereka. Pemeranan juga sedikit lebih dapat dirasakan hasilnya. Dalam pertemuan ke II (dua) inilah diadakan tes untuk mengukur keberhasilan metode.

Untuk mengukur tingkat kemampuan siswa tentang materi pembelajaran dalam pemeranan juga diadakan penilaian unjuk kerja. Berikut rekapitulasi penilaian unjuk kerja pada siklus I diajikan pada Tabel 4.3.

Tabel 4.3 Rekapitulasi Nilai Unjuk Kerja Siklus I

\begin{tabular}{|c|l|c|c|c|c|c|c|c|c|}
\hline \multirow{2}{*}{ No } & \multirow{2}{*}{ Aspek yang dinilai } & \multicolumn{6}{|c|}{ Skor } \\
\cline { 3 - 10 } & & \multicolumn{2}{|c|}{4} & \multicolumn{2}{|c|}{3} & \multicolumn{2}{|c|}{2} & \multicolumn{2}{|c|}{1} \\
\cline { 3 - 10 } & & Jml & $\%$ & Jml & $\%$ & Jml & $\%$ & Jml & $\%$ \\
\hline 1 & $\begin{array}{l}\text { Mengucapkan kata/huruf } \\
\text { dengan lafal yang benar }\end{array}$ & 3 & 15,8 & 6 & 31,8 & 8 & 42,1 & 2 & 10,5 \\
\hline 2 & $\begin{array}{l}\text { Menggunakan intonasi dengan } \\
\text { tepat }\end{array}$ & 1 & 5,3 & 6 & 31,8 & 10 & 52,6 & 2 & 10,5 \\
\hline 3 & $\begin{array}{l}\text { Kesesuaian ekspresi dengan } \\
\text { pernyataan }\end{array}$ & 4 & 21,1 & 4 & 21,1 & 8 & 42,1 & 2 & 10,5 \\
\hline 4 & $\begin{array}{l}\text { Tidak mengulang-ulang } \\
\text { pernyataan }\end{array}$ & 1 & 5,3 & 7 & 36,8 & 10 & 52,6 & 1 & 5,3 \\
\hline
\end{tabular}


Berdasarkan tabel diatas, dengan adanya penggunaan metode bermain peran, secara riil siswa dapat mempraktikkan keterampilan dalam materi dengan kriteria yang diharapkan sesuai dengan aspek yang dinilai pada lembar unjuk kerja diatas. Akan tetapi pencapaian keterampilan tersebut belum tercapai secara maksimal. Perolehan skor pada tiap aspeknya masih kurang memuaskan, hal ini akan menjadi evaluasi pada siklus ke II untuk lebih efisien dalam menerapkan metode ini (bermain peran).Selain dengan adanya tes, observasi dan penilaian unjuk kerja dari peneliti, siswa juga diberikan angket di setiap akhir siklusnya. Hasil angket pada siklus I disajikan pada Tabel 4.4 .

Tabel 4.4 Hasil Pengamatan Aktifitas Sikap Siswa Pada Siklus 1

\begin{tabular}{|c|l|c|c|}
\hline \multirow{2}{*}{ No } & \multicolumn{1}{|c|}{ Uraian } & Jawaban & $\begin{array}{c}\text { Persentase } \\
(\%)\end{array}$ \\
\hline \multirow{2}{*}{1} & Apakah pembelajaran dengan bermain peran menyenangkan? & Ya & 63,15 \\
\cline { 2 - 4 } & & Tidak & 36,85 \\
\hline \multirow{2}{*}{3} & Apakah kamu malu untuk bertanya pada waktu pembelajaran? & Ya & 68,42 \\
\cline { 2 - 4 } & Apakah belajar dengan bermain peran memudahkan untuk & Tidak & 31,58 \\
\hline \multirow{2}{*}{4} & memahami materi? & Ya & 42,10 \\
\cline { 2 - 4 } & peran? & Tidak & 57,90 \\
\hline \multirow{2}{*}{5} & $\begin{array}{l}\text { Apakah dengan belajar bermain peran kamu dapat menulis } \\
\text { kata/kalimat dalam bahasa Inggris? }\end{array}$ & Tidak & 73,68 \\
\cline { 2 - 4 } & & Ya & 26,32 \\
\hline
\end{tabular}

Dari pengamatan serta hasil angket diatas tampak bahwa sikap siswa biasa-biasa saja. Hal ini dikarenakan anak masih belum sepenuhnya dapat mengaitkan realitas dengan materi pembelajaran (Spelling dan membuat kalimat perintah) serta sebagian besar anak belum memahami tentang aturan untuk belajar dengan bermain peran.Keberanian anak untuk mengungkapkan gagasannya belum begitu nampak, karena sebelum adanya tindakan kelas anak terbiasa berinteraksi dengan guru saja tanpa mereka harus berdiskusi dengan temannya. Hal ini dapat dimaklumi karena anak masih dalam tahap penyesuaian.

Hasil belajar secara klasikal dalam siklus I belum mencapai ketuntasan. Hal ini dikarenakan kurangnya waktu karena guru dan siswa masih dalam tahap penyesuaian, serta anak 
belum begitu tanggap dalam mengamati dan memahami materi yang disampaikan melalui pemeranan.

Seperti halnya di siklus I, pembelajaran siklus II dilaksanakan dalam 2 kali pertemuan. Pertemuan pertama pada hari Rabu tanggal 07 Februari 2018 dan pertemuan kedua pada hari Rabu tanggal 14 Februari 2018. Pengamatan dilakukan di kelas IV MI Thoriqotul Falah Talangkembar Kecamatan Montong, dengan jumlah siswa 19 orang terdiri dari 9 siswa laki-laki dan 10 siswa perempuan dengan keadaan kelas heterogen.

Pada tahap ini peneliti berperan sebagai mitra guru atau observer. Peneliti bertugas mencatat setiap hal yang terjadi selama proses pembelajaran. Pelaksanaan di siklus II mengacu kepada RPP yang telah dibuat dengan mempertimbangkan refleksi dari siklus I, sehingga kesalahan yang terjadi di siklus I tidak terulang di proses pembelajaran siklus II.

Pada kegiatan di akhir pembelajaran pertemuan kedua di siklus II diadakan tes formatif. Tes ini dilakukan guna mengukur tingkat keberhasilan penggunaan metode yang berpengaruh pada hasil belajar. Berikut rekapitulasi hasil belajar pada siklus II disajiakan pada Tabel 4.5.

Tabel 4.5 Rekapitulasi Hasil Belajar Siklus II

\begin{tabular}{|c|l|c|c|}
\hline \multirow{2}{*}{ No } & \multirow{2}{*}{ Uraian } & \multicolumn{2}{c|}{ Hasil } \\
\cline { 3 - 4 } & & Jumlah & \% \\
\hline $\mathbf{1}$ & Jumlah siswa yang tuntas belajar & 2 & 17 \\
\hline $\mathbf{2}$ & Jumlah siswa yang tidak tuntas belajar & \multicolumn{2}{|c|}{$\mathbf{7 7 , 3 7}$} \\
\hline Rata-rata kelas (Mean) & \multicolumn{2}{|c|}{$\mathbf{8 9 , 5 0 \%}$} \\
\hline Ketuntasan klasikal & \\
\hline
\end{tabular}

Berdasarkan Tabel 4.5 dapat diketahui bahwa setelah dilakukan tindakan kedua kalinya hasilnya sangat berbeda dengan sebelumnya. Nilai rata-rata yang semula pada siklus I 75,68 pada siklus II mencapai 77,37. Hal ini menunjukkan bahwa dengan adanya penggunaan metode bermain peran memberikan peningkatan terhadap hasil belajar siswa. Jumlah siswa tuntas juga selalu menigkat ditiap siklusnya, yang semula 9 anak pada tahap pra siklus, meningkat menjadi 12 anak pada siklus I, dan 17 anak pada siklus II. Ketuntasan klasikal pada siklus II sudah mencapai ketuntasan yang diharapkan $(\leq 85 \%)$. Ketuntasan klasikal pada tahap siklus II mencapai $89,50 \%$, hal ini lebih tinggi dari target ketuntasan yang diharapkan. 
Hasil pengamatan untuk siswa difokuskan pada sikap serta respon siswa dalam mengukuti pembelajaran. Hasil pengamatan sikap siswa pada siklus II disajikan dalam tabel berikut:

Tabel 4.6 Hasil Pengamatan Aktifitas Sikap Siswa Pada Siklus 2

\begin{tabular}{|c|l|c|c|c|c|}
\hline \multirow{2}{*}{ No. } & \multicolumn{2}{|c|}{ Uraian } & \multicolumn{3}{c|}{ Jumlah } \\
\cline { 3 - 6 } & & Ya & Tidak & \\
\hline 1. & Semangat siswa dalam belajar & 16 & 84,21 & 3 & 15,79 \\
\hline 2. & Antusiasme siswa dalam belajar & 14 & 73,68 & 5 & 26,32 \\
\hline 3. & Keaktifan dan respon siswa dalam belajar & 16 & 84,21 & 3 & 15,79 \\
\hline 4. & Kekritisan siswa dalam belajar & 12 & 63,15 & 7 & 36,85 \\
\hline 5. & Disiplin siswa dalam mengikuti pelajaran & 17 & 89,50 & 2 & 10,50 \\
\hline
\end{tabular}

Dari tabel 4.6 dapat diuraikan bahwa pada pembelajaran siklus II, sikap siswa mengalami perubahan yang sangat dominan. Setiap aspek sikap mengalami adanya peningkatan. Hal ini dikarenakan siswa sudah dapat beradaptasi dengan penggunaan metode, dengan pengalaman yang di dapat pada siklus I. Kesetiap aspek memang tidak mencapai 100\%, akan tetapi telah melewati lebih dari $50 \%$.Siswa lebih aktif dan partisipatif dalam mengikuti pembelajaran.

Untuk tingkat kemampuan siswa tentang materi pembelajaran dalam pemeranan juga diadakan penilaian unjuk kerja. Berikut rekapitulasi penilaian unjuk kerja pada siklus II disajikan pada Tabel 4.7 .

Tabel 4.7 Rekapitulasi Nilai Unjuk Kerja Siklus 2

\begin{tabular}{|c|c|c|c|c|c|c|c|c|c|}
\hline \multirow{3}{*}{ No } & \multirow{3}{*}{ Aspek yang dinilai } & \multicolumn{8}{|c|}{ Skor } \\
\hline & & \multicolumn{2}{|c|}{4} & \multicolumn{2}{|c|}{3} & \multicolumn{2}{|c|}{2} & \multicolumn{2}{|c|}{1} \\
\hline & & $\mathrm{Jml}$ & $\%$ & $\mathrm{Jml}$ & $\%$ & $\mathrm{Jml}$ & $\%$ & $\mathrm{Jml}$ & $\%$ \\
\hline 1 & Mengucapkan kata/huruf dengan & 10 & 52,6 & 8 & 42,1 & 1 & 5,3 & 0 & 0 \\
\hline
\end{tabular}




\begin{tabular}{|c|c|c|c|c|c|c|c|c|c|}
\hline & lafal yang benar & & & & & & & & \\
\hline 2 & $\begin{array}{l}\text { Menggunakan intonasi dengan } \\
\text { tepat }\end{array}$ & 7 & 36,8 & 9 & 47,4 & 3 & 15,8 & 0 & 0 \\
\hline 3 & $\begin{array}{l}\text { Kesesuaian ekspresi dengan } \\
\text { pernyataan }\end{array}$ & 7 & 36,8 & 11 & 57,9 & 1 & 5,3 & 0 & 0 \\
\hline 4 & $\begin{array}{l}\text { Tidak mengulang-ulang } \\
\text { pernyataan }\end{array}$ & 10 & 52,6 & 6 & 31,8 & 3 & 15,8 & 0 & 0 \\
\hline
\end{tabular}

Pada tabel 4.7 diatas dapat diketahui bahwa terdapat perkembangan kemampuan siswa dalam praktik bermain peran. Keempat aspek yang difokuskan dapat dilakukan oleh siswa, serta skor minimal 2. Secara keseluruhan siswa dapat menguasai aspek yang ditekankan, hal ini dibuktikan dengan banyaknya siswa yang memperoleh skor 3 dan 4 dalam setiap aspek. Pencapaian tersebut dirasa sangat cukup, karena berarti kemampuan dan keterampilan siswa dalam berbahasa terutama pada materi Spelling dirasa telah maksimal.

Peningkatan sikap siswa sangat dapat dirasakan daripada siklus sebelumnya. Siswa lebih percaya diri dan kreatif dalam mengembangkan gagasannya. Seperti halnya pada siklus I, di pertemuan kedua siklus II diadakan tes formatif. Selain mengisi tes, siswa juga mengisi lembar angket yang dibagikan guru. Adapun hasil angket pada siklus II disajikan pada Tabel 4.8,

Tabel 4.8 Hasil Pengamatan Aktifitas Sikap Siswa Pada Siklus 1

\begin{tabular}{|c|c|c|c|}
\hline No & Uraian & Jawaban & $\begin{array}{l}\text { Persentase } \\
(\%)\end{array}$ \\
\hline \multirow[t]{2}{*}{1} & \multirow[t]{2}{*}{ Apakah pembelajaran dengan bermain peran menyenangkan? } & Ya & 89,5 \\
\hline & & Tidak & 10,5 \\
\hline \multirow[t]{2}{*}{2} & \multirow[t]{2}{*}{ Apakah kamu malu untuk bertanya pada waktu pembelajaran? } & Ya & 89,5 \\
\hline & & Tidak & 10,5 \\
\hline \multirow[t]{2}{*}{3} & \multirow{2}{*}{$\begin{array}{l}\text { Apakah belajar dengan bermain peran memudahkan untuk } \\
\text { memahami materi? }\end{array}$} & $\mathrm{Ya}$ & 84,2 \\
\hline & & Tidak & 15,8 \\
\hline \multirow[t]{2}{*}{4} & \multirow{2}{*}{$\begin{array}{l}\text { Apakah kamu mengalami kesulitan dalam belajar dengan } \\
\text { bermain peran? }\end{array}$} & $\mathrm{Ya}$ & 31,6 \\
\hline & & Tidak & 68,4 \\
\hline \multirow[t]{2}{*}{5} & \multirow{2}{*}{$\begin{array}{l}\text { Apakah dengan belajar bermain peran kamu dapat menulis } \\
\text { kata/kalimat dalam bahasa Inggris? }\end{array}$} & $\mathrm{Ya}$ & 73,7 \\
\hline & & Tidak & 26,3 \\
\hline
\end{tabular}


Berdasarkan hasil rekapitulasi angket di siklus II diatas maka dapat disimpulkan bahwa, sikap siswa dalam mengikuti pembelajaran semakin menunjukkan keaktifan dan antuasiasme. Secara keseluruhan aspek dalam angket dapat diterima oleh siswa. Tingkat ketertarikan siswa tinggi.Pembelajaran dapat dirasa menyenangkan, kemampuan bertanya siswa juga berkembang, serta siswa dapat dengan mudah memahami materi dikarenakan materi digambarkan dalam pemeranan. Kesulitan belajar dapat diminimalisir dengan pembelajaran tersebut, serta kemampuan menulis siswa juga semakin baik.Pada siklus II guru telah menerapkan pembelajaran dengan baik. Hal ini terlihat dari semangat dan keaktifan siswa dalam mengikuti proses pembelajaran, perkembangan keterampilan siswa dalam berperan, juga meninjau hasil belajar (kognitif) yang terus meningkat di setiap siklusnya. Dari rata-rata kelas, jumlah siswa belajar serta ketuntasan klasikal juga meningkat setiap siklusnya. Rekapitulasi keseluruhan peningkatan dapat digambarkan pada Grafik 4.1

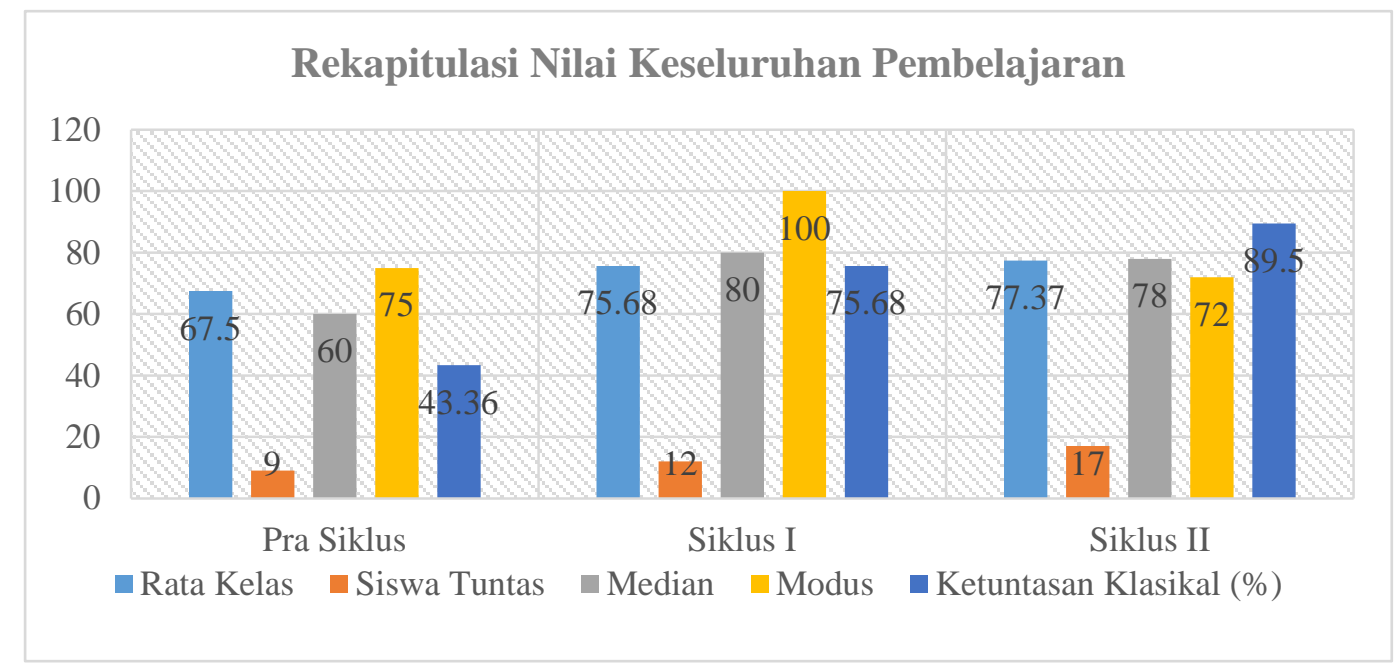

Grafik 4.1 Rekapitulasi keseluruhan peningkatan Pembelajaran

Berdasarkan Grafik 4.1 dapat disimpulkan bahwa, setiap siklusnya sangat memberikan perubahan yang begitu berarti. Hasil yang dicapai dalam setiap siklus dapat dikatakan sangat memuaskan karena dalam setiap tahap mengalami peningkatan. Hal ini dikarenakan guru dapat menerapkan metode secara maksimal, serta siswa berperan sangat baik dalam pembelajaran. Adanya evaluasi dengan mempertimbangkan refleksi dari siklus sebelumnya, menjadi kunci keberhasilan pembelajaran di siklus II. 
Berdasarkan hasil penelitian, terdapat 2 (dua) fokus yang dibahas dalam penelitian tindakan kelas ini. Fokus pembahasan tersebut yakni aktivitas guru dan siswa dan ketuntasan hasil belajar siswa. Selama pembelajaran berlangsung dengan menggunakan metode bermain peran. Guru dan siswa saling berinteraksi dalam proses kegiatan belajar mengajar (KBM). Data observasi guru,aspek dalam setiap sintak telah banyak terlaksana. Hal ini menandakan bahwa kemampuan guru dalam mengelola kelas meningkat, yang akhirnya berdampak positif terhadap prestasi belajar siswa yang dapat ditunjukkan dengan meningkatnya nilai rata-rata siswa dari siklus I ke siklus II. Guru sebagai mediator dan fasilitator juga sangat mengoptimalisasi perannya. Terdapat 2 aspek yang belum dilaksanakan oleh guru hingga siklus II. Hal tersebut bukan menjadi masalah dikarenakan telah banyak aspek yang dilakukan oleh guru, serta keberhasilan pembelajaran telah mencapai ketuntasan secara klasikal.

Berdasarkan analisis data, diperoleh aktifitas siswa dalam proses belajar Bahasa Inggris dengan bermain peran terasa lebih semangat, sebab prinsipnya belajar sambil bermain, terjadi diskusi antar siswa, tanya-jawab antar siswa dan guru, siswa mendengarkan dan memperhatikan penjelasan guru. Jadi dapat dikatakan bahwa aktivitas siswa di siklus II dapat dikategorikan lebih aktif dibanding siklus I. Sikap dan respon siswa semakin baik.

Setiap aspek sikap siswa mengalami peningkatan yang cukup berarti. Peningkatan terbesar terjadi pada aspek nomor 4, yakni aspek kekritisan siswa dalam belajar. Hal ini menunjukkan bahwa siswa semakin percaya diri dalam mengekspresikan dirinya dalam belajar dengan bermain peran, siswa aktif bertanya daripada pembelajaran sebelum adanya tindakan kelas. Hal ini sesuai dengan teori bahwa melalui bermain peran, para peserta didik mencoba mengeksplorasi hubungan-hubungan antarmanusia dengan cara memperagakannya dan mendiskusikannya sehingga secara bersama-sama para peserta didik dapat mengeksplorasi perasaan-perasaan, sikap-sikap, nilai-nilai, dan berbagai strategi pemecahan masalah. ${ }^{5}$

Selain itu hasil angket siswa juga meningkat dalam setiap aspeknya, hal tersebut merupakan efek positif dari adanya penerapan metode bermain peran. Belajar dengan metode bermain peran direspon sangat baik oleh siswa, serta antusiasme siswa sangat tinggi. Kesulitan belajar pada materi spelling dan membuat kalimat/ungkapan dapat teratasi meskipun kemampuan menulis siswa mencapai hasil yang sedikit, tapi sudah lebih dari cukup. Selain itu, hal terpenting adalah pemahaman materi, karena hal tersebut sangat berpengaruh dalam peningkatan hasil 
belajar.Hal tersebut sesuai dengan teori bahwa salah satu manfaat metode pembelajaran bermain peran adalah siswa terlatih untuk memahami, dan mengingat isi materi bahan yang akan didramakan dalam pembelajaran. ${ }^{6}$

Penelitian ini menunjukkan bahwa pembelajaran dengan menggunakan metode bermain peran berdampak positif dalam meningkatkan prestasi belajar siswa. Hal ini dapat dilihat dari semakin meningkatnya pemahaman siswa terhadap materi spelling dan membuat kalimat perintah/ungkapan pada pelajaran Bahasa Inggris yang disampaikan guru. Ketuntasan klasikal meningkat pada tiap tahapnya, yaitu 43,36\% sebelum siklus dilaksanakan menjadi 75,68\% pada siklus I dan terus meningkat menjadi $89,50 \%$ di siklus II. Sehingga dapat disimpulkan bahwa pada siklus II ketuntasan belajar siswa secara klasikal telah tercapai.Selain pertimbangan pada hasil belajar dengan tes formatif. Ketuntasan ini juga dipertimbangkan pada peningkatan kemampuan siswa pada keterampilan berbahasa dalam materi spelling dan imperative sentences dengan penilaian unjuk kerja pada saat siswa praktik berperan.

\section{Kesimpulan dan Saran}

Berdasarkan hasil penelitian yang diperoleh selama melakukan penelitian tindakan kelas tentang penerapan metode belajar dengan bermain peran secara bersama dalam kelompok untuk meningkatkan aktivitas belajar siswa dalam mata pelajaran Bahasa Inggris di kelas IV MI Thoriqotul Falah Talangkembar kecamatan Montong pada tahun pelajaran 2017-2018, maka dapat diambil kesimpulan:

1) Penerapan metode belajar dilaksanakan guru dengan baik. Guru menerapkan setiap sintak kegiatan secara maksimal. Tahap-tahap pembelajaran dilakukan berdasarkan sintak pembelajaran dengan metode bermain peran. Berdasarkan pengamatan 90,9\%, guru telah melaksanakan pembelajaran sesuai dengan tahapan belajar dengan bermain peran. Maka dari itu, dalam pembelajaran ini dikatakan bahwa penerapan telah dilakukan secara maksimal.

2) Hasil belajar siswa mengalami peningkatan pada setiap siklusnya. Hasil belajar disini bukan hanya ditekankan pada tes tertulis (penilain kognitif), melainkan juga dengan pertimbangan pada kenaikan respon/sikap siswa terhadap pembelajaran (afektif), serta penilaian unjuk kerja siswa selama proses pemeranan (aspek psikomotorik). Penerapan

${ }^{6}$ lbid 
metode yang sebelumnya didahului dengan refleksi awal sebagai dasar diadakannya penelitian, menghasilkan perubahan yang sangat berarti pada hasil belajar siswa. Peningkatan hasil belajar siswa dipengaruhi oleh adanya peningkatan kemampuan siswa dalam keterampuan berbahasa yang dibuktikan dengan naiknya nilai nsiswa pada unjuk kerja. Dengan begitu siswa dikatakan tuntas jika mencapai hasil belajar tes kognitif dan meningkat pada aspek afektif, dan penilaian unjuk kerja pada sisi psikomotorik.

Untuk mengatasi permasalahan di lembaga, peneliti memberikana saran sebaiknya guru selalu menciptakan inovasi dalam pembelajaran. Sebagai contoh inovasi dalam metode mengajar yang dilakukan pada penelitian ini yaitu metode bermain peran. Metode ini memang tidak dapat digunakan pada semua materi, akan tetapi dapat di desain sedemikian rupa oleh guru agar dapat diterapkan dalam pembelajaran. Keberhasilan suatu metode akan memberikan dampak yang baik pula dalam pembelajaran.

Metode belajar dengan bermain peran ini melibatkan siswa secara langsung untuk berpartisipasi dalam pembelajaran, dengan adanya hal tersebut pembelajaran akan terkesan menyenangkan. Masalah yang diperankan juga akan memberikan gambaran secara nyata kepada siswa, hal ini akan memudahkan siswa untuk menanggapi suatu materi. Dengan semangat dan kesenangan untuk belajar serta antusiasme siswa dalam belajar akan menciptakan hal yang positif. Kemudahan memahami materi akan berdampak pada hasil belajar siswa, dikarenakan pemahaman mendalam tentang materi akan memudahkan siswa untuk menyelesaikan tugas yang diberikan oleh guru dalam setiap mata pelajaran.

Dengan demikian berdasarkan pada hasil penelitian ini, keberhasilan suatu pembelajaran tergantung pada bagaimana guru menginovasi dan menciptakan kreasi dalam pembelajaran. Selain itu peran siswa yang aktif, kritis, dan kompetitif juga sangat memberikan dampak pada keberhasilan suatu pembelajaran. Untuk menciptakan siswa aktif kemampuan guru mengelola kelas sangat berpengaruh.

\section{Referensi}

Huda, Miftahul. 2013. Model-model Pengajaran dan Pembelajaran: Isu-isu Metodis dan Paradigmatis, Cet III. Yogyakarta: Pustaka Pelajar.

Mukarto, dkk. 2007. Grow With English. Jakarta: Erlangga 
Mulyasa, E. 2014. Manajemen Pendidikan Karakter, Cet IV. Jakarta: PT. Bumi Aksara.

Rizky. 2013. Kelebihan dan Kelemahan Metode Bermain Peran atau Sosiodrama, (Online), http://pedulidenganmenulis.blogspot.co.id/2013/02/kelebihan-dan-kelemahan-metodebermain.html, (diakses tanggal 30 Maret 2018). 